\title{
Further Studies on the Relationship of the Stimulatory Effects of Phenobarbital and 3,4-Benzpyrene on Hepatic Heme Synthesis to Their Effects on Hepatic Microsomal Drug Oxidations ${ }^{1}$
}

\author{
J. BARON ${ }^{2}$ AND T. R. TEPHLY \\ Department of Pharmacology, The University of Michigan Medical School, The University of \\ Michigan, Ann Arbor, Michigan 48104
}

Received April 9, 1970; accepted May 26, 1970

\begin{abstract}
The administration of either phenobarbital or 3,4-benzpyrene to rats resulted in the rapid and marked induction of $\delta$-aminolevulinic acid synthetase (EC 2.3.1.13), the proposed initial and rate-limiting enzyme in the hepatic heme biosynthetic pathway. Enhanced formation of $\delta$-aminolevulinic acid was followed sequentially by an enhancement of the liver's capacity to synthesize microsomal heme in vivo, increases in the content of cytochrome P-450 and protoheme in hepatic microsomes and stimulation of certain hepatic microsomal drug oxidations.

Changes in the hepatic microsomal levels of cytochrome P-450 paralleled, in part, changes in the activity of hepatic $\delta$-aminolevulinic acid synthetase and in the capacity of the liver to synthesize microsomal heme in vivo, suggesting that the rate of hepatic heme synthesis may control the rate of synthesis of hepatic microsomal cytochome P-450. Increases in the hepatic microsomal content of cytochrome $\mathrm{b}_{5}$, however, followed a different time course from that observed from either cytochrome $\mathbf{P}$. 450 or protoheme.

The simultaneous administration of maximum stimulatory doses of phenobarbital and 3,4 -benzpyrene did not result in an additive stimulation of $\delta$ aminolevulinic acid synthetase activity, indicating that phenobarbital and 3,4-benzpyrene induce $\delta$ aminolevulinic acid synthetase by the same or closely related mechanisms. However, the stimulatory effects of these agents on cytochrome $P-450$ and on the $N$-demethyla tion of 3-methyl-4-monomethylaminoazobenzene were additive, suggesting that differences may exist in the mechanism by which phenobarbital and 3,4 -benzpyrene induce hepatic microsomal cy tochrome $\mathrm{P}-450$ and enhance certain hepatic microsomal drug oxidations.
\end{abstract}

'Treatment of animals with certain drugs, such as phenobarbital, and carcinogens, such

\footnotetext{
${ }_{1}$ This research was supported in part by United States Public Health Service Grant AM-12168 and in part by National Institute of (Ceneral Medical Sciences Grant 1P-11-GM-15559. The data reported herein appeared in a thesis submitted by $J$. Baron in partial fulfilment of the requirements for the degrce of Doctor of Philosophy to the I)partment of Pharmacology, The University of Michigan, 1969.

2 Present address : Department of Biochemistry, The University of Texas (Southwestern) Medical School at 1)allas, 1)allas, Texas 75235.
}

as 3,4-benzpyrene, results in the enhancement of the hepatic microsomal oxidations of many drugs and carcinogens $(1,2)$. Stimulation of these oxidations appears to result, at least in part, from enhancement of the synthesis of cytochrome P-450 (3, 4), the hepatic microsomal hemoprotein which is considered to be the terminal oxidase in hepatic microsomal mixed-function oxidations (5, 6). Recently, evidence has been presented which demonstrates that many agents, including phenobarbital and 3,4 benzpyrene, are capable of inducing hepatic $\delta$-aminolevulinic acid synthetase (EC 
2.3.1.13) $(7-10)$, the proposed initial and rate-limiting enzyme in the hepatic heme biosynthetic pathway $(11,12)$. Enhanced formation of $\mathrm{Al}_{\mathrm{A}} \mathrm{A}^{3}$ would lead to an increased rate of synthesis of hepatic heme which in turn might result in the observed increase in the hepatic microsomal content of cylochrome P-450 and in the stimulation of certain hepatic microsomal drug oxidations. In accordance with this proposal, previous reports from this laboratory have demonstrated that enhanced heme synthesis is essential for the induction of cytochrome P-450 and the stimulation of hepatic microsomal drug oxidations $(10,13)$.

The studies described in the present report were undertaken in an attempt to elucidate the relationship between the stimulatory effects of phenobarbital and 3,4-benzpyrene on hepatic heme synthesis and their effects on the hepatic microsomal drug-metabolizing system. The existence of possible differences in the mechanism or mechanisms by which phenobarbital and 3,4-benzpyrene induce crtochrome $\mathrm{P}-450$ and enhance certain hepatic microsomal drug oxidations was also examined.

\section{MATHRIAL}

(ilucose-6-phosphate, yeast glucose-6-phosphate dekydrogenase, NAI)P $P^{+}$, NAIPPH (type 1), NAl)II (grade III), horse heart eytochrome $\mathrm{c}$ (1 ype III), and 3, 4-benzpyrene were obtained from sigma Chemical Company. (alycine-2 ${ }^{14} \mathrm{C}$ (specific activity $7.81 \mathrm{mCi} / \mathrm{mmole}$ ) was obtained from New lingland Nuclear Corporation. Ethylmorphine hydrochloride and norcodeine hydrochloride were purchased from Merek and Company, lnc. 3-CHzMAB was a generous gift from 1)r. J. A. Miller of the Mr Ardle Laboratory for Cancer Research of The Lniversity of Wisconsin, and actinomyein In was generously supplied by Merck and Company, Inr. All other chemical and hionemicals woro employed in the highest purity available.

\section{MFTHODS}

\section{Treatment of Animals}

Male albino Holtzman rats weighing $130-170 \mathrm{~g}$ were used throughout these studies. Phenobarbital sodium was dissolved in $0.9 \% \mathrm{NaCl}$ and was ad-

${ }^{3}$ The abbreviations used are: ALA, $\delta$-aminolovulinic acid; 3-CH, $-\mathrm{MAB}, 3$-methyl-4-monomet hylaminoazobenzene. ministered at a dose of $40 \mathrm{mg} / \mathrm{kg}$, while 3 , 4-benzpyrene was dissolved in corn oil and was administered at a dose of $20 \mathrm{mg} / \mathrm{kg}$. These doses were found to produce maximum inductive effeets. Cont rol animals received an equal volume of $0.9 \%$ $\mathrm{NaCl}$ and/or corn oil. Actinomycin D was dissolved in propylene glycol and was administered at a dose of $3 \mathrm{mg} / \mathrm{kg}$. All agents were administered intraperitoneally. Rats were fasted for $24 \mathrm{hr}$ prior to sacrifice but were given water ad libitum. In all experiments, the livers of at least two rats which received identical treatments were pooled upon homogenization.

\section{Preparation of Microsomes}

Rats were sacrificed by decapitation, and the livers were perfused in situ with ice-cold $0.9 \%$ $\mathrm{NaCl}$ prior to excision. A $25 \%$ (w/v) homogenate was prepared in $1.15 \% \mathrm{KCl}$ using a Dounce homogenizer with a loose pestle. The homogenate was centrifuged at $9000 \mathrm{~g}$ for $20 \mathrm{~min}$ at $04^{\circ}$ in a refrigerated Servall centrifuge to sediment unbroken cells, nuclei, and mitochondria. The postmitochondrial supernatant was then centrifuged at $104,000 \mathrm{~g}$ for $90 \mathrm{~min}$ in a Spinco Model L, ultracentrifuge to sectiment the microsomal fraction. The microsomal suspensions thus prepared were free of hemoglobin as motsured by the method of Nishibayashi and Sato (14).

\section{Enzymatic Assays}

Methods for the determinations of the $X$ demethylations of ethylmorphine and $3-\mathrm{CII}_{3}-$ MAB, the $O$-demethylation of norcodeine, and the activity of NAIPPH-cytochrome c reduetase in hepatic microsomes have been described previously (13). The content of protein, protoheme, and cytochromes $P-450$ and $b_{5}$ in the microsomal suspensions were determined as deseribed previously (13).

$\delta$-Aminolenulinic acid synthetase. The activity of ALA symt hetase was determined by measuring the rate of formation of ALA in hepatic homogenates employing a modification of the method of Marver el al. (15). liats were decapitated, and, after in situ perfusion of the livers, $33 \%(\mathrm{w} / \mathrm{v})$ homogenates were prepared in a $0.9 \% \mathrm{XaCl}$ solution containing $0.5 \mathrm{~mm}$ disodium ELTA and 10 mm Tris-HCl bulfer, pH 7.4. When livers from control rais were employed, reaction mixtures contained in a total volume of $10 \mathrm{ml} ; 1 \mathrm{mmole}$ of glycine, $100 \mu$ moles of disodium E1)TA, $750 \mu$ moles of Tris-HCl bufler (pH 7.2), and $2.5 \mathrm{ml}$ of homogenate. When livers from phenobarbital-treated or 3,4 -benzpyrene-1 reated rats were employed, reaction mixtures contained in a total volume of 2 $\mathrm{m}$; $200 \mu$ moles of glyoine, $20 \mu$ moles of disodium 
H)TA, $150 \mu$ moles of Tris-HCl buffer, $\mathrm{pH} 7.2$, and $0.5 \mathrm{ml}$ of homogenate. Incubations were carried out for $30 \mathrm{~min}$ in open, 25 -ml Erlenmeyer flasks at $37^{\circ}$ with shaking in a Dubnolf metabolic incubator and were terminated by the addition of $0.5 \mathrm{ml}$ of a $25 \%$ trichloroacetic acid (TCA) solution per 2 $\mathrm{ml}$ of reaction mixture. In order to subtract the endogenous AIA content of each liver, reactions were stopped at zero time by the addition of TCA. To measure the ALA formed in hepatic homogenates from control rats, $10 \mathrm{ml}$ of the 'ICA supernatant was concentrated to $0.5 \mathrm{ml}$ using a Buchler flask evaporator. After the addition of $1.5 \mathrm{ml}$ of glass distilled water, $1 \mathrm{ml}$ of the resulting solution was used for the determination. When hepatic homogenates from phenobarbital-treated or 3,4benzpyrene-treated rats were employed, $1 \mathrm{ml}$ of the TCA supernatant was used directly for the determination. The method of Tschudy ef al. (16) was used for the determination of ALA, except that $\mathrm{NaOH}$ was omitted during the formation of the AIA pyrrole. The results described in the present report are comparable to those obtained when ALA synthetase activity was determined employing the more sensitive and specific method of Irving and Flliot: (17).

\section{Incorporation of Precursors into Microsomal Heme in Vivo}

To study the liver's capacity to synthesize microsomal heme in vivo at various times after the onset of treatment with either phenobarbital or 3,4-benzpyrene, rats received an intraperitoneal injection of $30 \mu \mathrm{Ci}$ of glycine $-2-{ }^{14} \mathrm{C}$. After $45 \mathrm{~min}$, rats were sacrificed by decapitation and livers were perfused with $0.9 \% \mathrm{NaCl}$ to remove hemoglobin prior lo homogenization. Incorporation of glycine $-2{ }^{14} \mathrm{C}$ into hepatic microsomal heme was linear throughout the 45 -min pulse. Heme was extracted from the microsomal preparations using acid-acetone (13), and the protoheme content and radioactivity of the extracted microsomal heme was determined as described previously (13).

\section{RESULTS}

Effects of Phenobarbital and 3,4-Benzpyrene Treatments on the Activity of Hepatic $\delta$-Aminolevulinic Acid Synthetase

As seen in Fig. 1, a single injection of either phenobarbital or 3,4-benzpyrene resulted in a rapid and marked increase in the activity of hepatic ALA synthetase. The magnitude of stimulation resulting from the administration of 3,4-benzpyrene was about $50 \%$ of that observed after treatment with phenobarbital, although increases in ALA synthe-

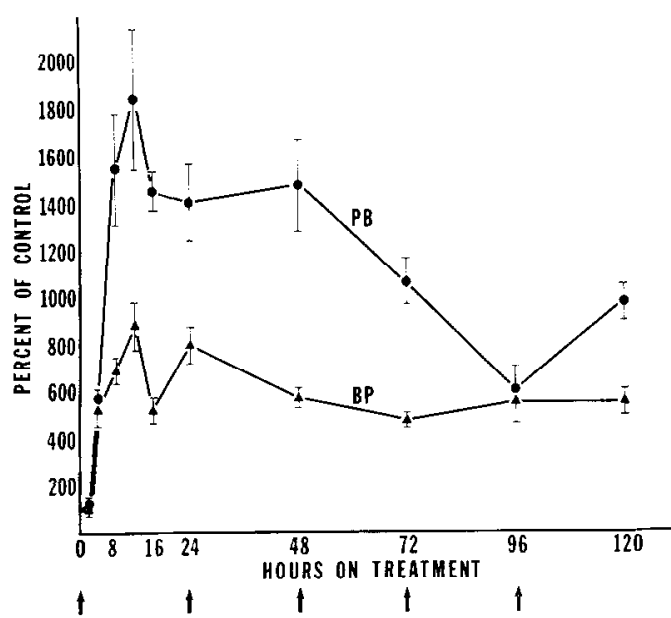

FIg. 1. Effects of phenobarbital and 3,4beuzpyrene treatments on the activity of hepatic ALA synthetase. Rats received intraperitoneal injections of either phenobarbital (PB) $(40 \mathrm{mg} /$ $\mathrm{kg}$ ) or 3,4 -benzpyrene (BP) $(20 \mathrm{mg} / \mathrm{kg})$ at the times indicated by the arrows. Control animals received an equal volume of $0.9 \% \mathrm{NaCl}$ or corn oil. Animals were sacrificed at the tines indicated, and the activity of ALA synthetase was determined in hepatic homogenates as described in the text. Each point represents the mean of at least 1 hree experiments, and the brackets represent the standard error of the mean. The average control value was $16.0 \mathrm{~m} \mu$ moles of ALA formed $/ \mathrm{g}$ liver $/ \mathrm{hr}$. All points were significantly $(P<0.05)$ increased over control values, except the value obtained 2 hr after the initial administration of 3,4-benzpyrene.

tase activity became maximal approximately $12 \mathrm{hr}$ after the initial administration of either agent. Once maximum stimulation was produced, however, the degree of enhancement of hepatic ALA synthetase activity declined, reaching a level 5 or 10 times greater than control values $120 \mathrm{hr}$ after the onset of treatment with 3,4-benzpyrene or phenobarbital, respectively. This decline vas not prevented by increasing the dose of eithcr agent during the last $72 \mathrm{hr}$ of the study, indicating that the apparent loss of stimulatory effect was not due to decreases in the effective concentrations of these agents during the late time periods of this study. Similar patterns for the stimulation of hepatic AIA synthetase activity by phenobarbital have been reported by Wada et al. (8) and by Tarver (9). 
Granick (18, 19) has suggested that the stimulation of hepatic ALA synthetase activity by compounds which enhance hepatic heme synthesis represents a true induction resulting from the increased de novo synthesis of the enzyme which can be prevented by inhibitors of protein and RNA synthesis. As seen in Table 1, the stimulatory effects of both phenobarbital and 3,4-benzpyrene on the activity of hepatic ALA synthetase also appear to be due to an induction, since the simultaneous administration of actinomycin D almost completely prevented any increase in the activity of ALA synthetase following the administration of either phenobarbital or 3,4-benzpyrene. Furthermore, when added in vitro to homogenates prepared from the livers of control rats, neither phenobarbital $\left(10^{-3} \mathrm{M}\right)$ nor 3 , 4-benzpyrene $\left(10^{-3}\right.$ iI) altered the activity of this enzyme, thereby indicating that the stimulation did not result from an activation of an already existing but inactive form of AIA synthetase.

\section{Effects of Phenobarbilal and 3,4-Benzpyrene Treatments on Hepatic Heme Synthesis in Vivo}

Previous studies have demonstrated that treatment of animals with either phenobarbital $(7-9,13,30)$ or 3,4-benzpyrene (10) results in the stimulation of the synthesis of hepatic microsomal heme. To study the relationship between the stimulation of hepatic ALA synthetase activity and the enhancement of hepatic heme synthesis pro duced by both phenobarbital and 3,4benzpyrene, the incorporation of $30 \mu \mathrm{Ci}$ pulse-dose of glycine-2 ${ }^{14} \mathrm{C}$ into hepatic microsomal heme was employed as an index of hepatic heme synthesis in vivo. In this manner, the capacity of the liver to synthesize microsomal heme in vivo was studied at various time intervals after the onset of treatment with either phenobarbital or 3,4benzpyrene. As scen in Table II, the amount of radioactivity incorporated into microsomal heme per gram of liver was significantly increased $(P<0.05)$ between $\&$ and $120 \mathrm{hr}$ after the onset of treatment with either agent, with maximum stimulation
TABLL: I

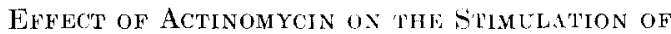
Hepatic ALA Syxthetase by Phenobarbital AND 3,4-BEXPPYRENE:

\begin{tabular}{lc}
\hline \multicolumn{1}{c}{ Treatment } & $\begin{array}{c}\text { m mmoles of } \mathrm{ALA} \\
\text { jormed } / \mathrm{g} \text { liver } / \mathrm{hr}^{b}\end{array}$ \\
\hline Control & $16.0 \pm 1.2$ \\
Phenobarbital & $97.2 \pm 14.0$ \\
Actinomycin D & $12.0 \pm 2.1$ \\
Phenobarbital + & $25.4 \pm 2.4^{c}$ \\
$\quad$ actinomycin D & $83.6 \pm 14.0$ \\
3,4-Benzpyrene & $23.9 \pm 1.7^{d}$ \\
3,4-Benzpyrene + & \\
actinomycin D &
\end{tabular}

a Rats received intraperitoneal injections of actinomycin D (3 $\mathrm{mg} / \mathrm{kg})$ and/or cither phenobarbital $(40 \mathrm{mg} / \mathrm{kg}$ ) or 3,4 -benzpyrene $(20 \mathrm{mg} / \mathrm{kg})$ at zero time. Control animals received an equal volume of propylene glycol and/or either $0.9 \%$ $\mathrm{NaCl}$ or corn oil. Four hours later, animals were sacrificed, and the activity of ALA synthetase was determined in hepatic homogenates as described in the text.

${ }^{b}$ Each value represents the mean \pm standard error of at least three experiments.

c Values are significantly lower $(P<0.05)$ than the values obtained after 1 reatment with phenobarbital alone.

${ }^{2}$ Values are significantly lower $(P<0.05)$ than the values obtained after treatment with 3, 4-benzpyrene alone.

occurring after approximately $48 \mathrm{hr}$. The incorporation of ${ }^{59} \mathrm{FeCl}_{3}$ into hepatic microsomal heme in vivo has previously been observed to be stimulated as early as $4 \mathrm{hr}$ after the administration of phenobarbital (13).

The stimulatory effects of phenobarbital and 3,4-benzpy rene on the liver's capacily to synthesize microsomal heme in vivo appeared to parallel their effects on the activity of hepatic ALA synthetase (Fig. 1), although changes in the activity of this enzyme appeared to precede changes in hepatic heme synthesis in vivo. Furthermore, in agreement with the effects of these agents on the activity of hepatic ALA synthetase, the enhancement of hepatic heme synthesis in vivo observed after treatment with 3,4 benzpyrene was approximately $50 \%$ of that observed after the administration of phenobarbital. 
TABLE II

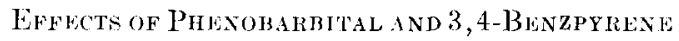
Treatments on the Capacity of the Liver to Sinteriesize Michosomal Heme in Vivo ${ }^{a}$

\begin{tabular}{cll}
$\begin{array}{c}\text { IIours on } \\
\text { treatment }\end{array}$ & \multicolumn{2}{c}{ Percent of control } \\
\cline { 2 - 3 } & Phenobarbital & $3,4-$-Benzpyrene \\
\hline 2 & $115 \pm 18$ & $112 \pm 11$ \\
4 & $110 \pm 0^{\circ}$ & $107 \pm 5$ \\
8 & $131 \pm 10^{\circ}$ & $118 \pm 6^{\circ}$ \\
12 & $217 \pm 29^{\circ}$ & $156 \pm 23^{\circ}$ \\
16 & $240 \pm 14^{\circ}$ & $163 \pm 6^{\circ}$ \\
24 & $283 \pm 30^{\circ}$ & $170 \pm 7^{\circ}$ \\
48 & $327 \pm 10^{\circ}$ & $197 \pm 7^{\circ}$ \\
72 & $243 \pm 18^{\circ}$ & $157 \pm 10^{\circ}$ \\
96 & $188 \pm 11^{\circ}$ & $141 \pm 21^{\circ}$ \\
120 & $173 \pm 18^{\circ}$ & $141 \pm 21^{\circ}$ \\
\hline
\end{tabular}

a Phenobarbital (40 mg/kg) or 3,4-benzpyrene $(20 \mathrm{mg} / \mathrm{kg}$ ) were administered intraperitoneally to rats every $24 \mathrm{hr}$. Control animals received an equal volume of $0.9 \% \mathrm{NaCl}$ or com vil. At the times indicated, rats received intraperitoneally a 45 -min pulse-dose of $30 \mu \mathrm{Ci}$ of glycine-2- ${ }^{14} \mathrm{C}$, and incorporation of isotope into extracted hepatic microsomal heme was determined. The average control value was $755110 \mathrm{pm}$ in microsomal heme per gram of liver.

"Wach value represents the mean \pm standard error of at least three experiments.

${ }^{\circ} P<0.05$.

Effects of Thenobarbital and 3,4-Benzpyrene Treatments on the Hepatic Microsomal Content of Protoheme and Protein.

Treatment of rats with either phenobarbital or 3,4-benzpyrene resulted in the elevation of the hepatic microsomal content of protoheme as seen in Fig. 2 and in Tables III and IV. The amount of microsomal protoheme per milligram of microsomal protein and per gram of liver was significantly increased $(P<0.05) 8 \mathrm{hr}$ after phenobarbital administration and $12 \mathrm{hr}$ after the administration of 3,4-benzpyrene. Protoheme levels romaincd clovated during the remainder of the study, increasing to a maximum 72-96 hr after the onset of treatment with either agent, and then declining toward control values during the last, 24 to $48 \mathrm{hr}$ of the study. In accordance with the effects of these agents on the activity of hepatic ALA synthetase and hepatic heme synthesis, increases in the hepatic micro- somal content of protoheme produced by 3,4-benzpyrene was approximately $50 \%$ of that observed after phenobarbital treat. ment.

In agreement with the observations of other investigators $(20-22)$, phenobarbital treatment resulted in an increased amount of microsomal protein per gram of liver (Table III). Treatment of rats with 3,4benzpyrene was also observed to result in an increased amount of microsomal protein per gram of liver (Table IV), although this stimulat.ory effect was not very marked.

\section{Effects of Phenobarbital and 3,4-Benzpyrene Treatments on Hepatic Microsomal. Cytochromes}

The effects of phenobarbital and 3,4benzpyrene treatments on the content of cytochrome P-450 in hepatic microsomes are summarized in Fig. 3 and in Tables III and IV. The amount of cytochrome P-450 per milligram of microsomal protein and per gram of liver was significantly increased $(P<0.05) 8 \mathrm{hr}$ after phenobarbital administration and 12 hr after the onset of 3,4 benzpyrene treatment. The amount of cytochrome P-450 in hepatic microsomes

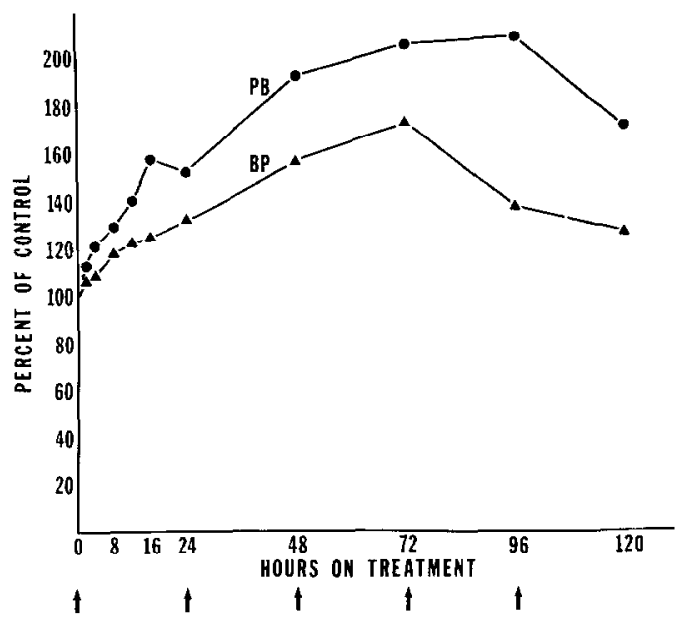

Fra. 2. Efferts of phenobarbital and 3,4 benzpyrene treatments on the hepatic microsomal content of protoheme. Conditions were the same as described for Fig. 1. Each point represents the mean of at least three experiments. The average control value was 1.06 m $\mu$ moles of protoheme $/ \mathrm{mg}$ protein. 
TABLL III

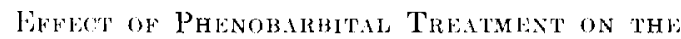
Contlint of Microsomal Protela, Proto-

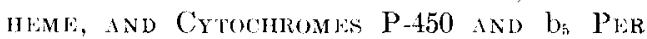
(IRAM OF LAVER ${ }^{\text {th }}$

\begin{tabular}{r|c|c|c|c}
$\begin{array}{c}\text { Hours } \\
\text { on } \\
\text { treat- } \\
\text { ment }\end{array}$ & \multicolumn{4}{|c}{ Percent of control } \\
& Protein & Protoheme & $\begin{array}{c}\text { Cytochome } \\
\text { P-450 }\end{array}$ & $\begin{array}{c}\text { Cytochrome } \\
b_{5}\end{array}$ \\
\hline 2 & $10 \pm \pm 4$ & $119 \pm 19$ & $112 \pm 8$ & $114 \pm 17$ \\
4 & $91 \pm 8$ & $111 \pm 16$ & $101 \pm 14$ & $101 \pm 9$ \\
8 & $94 \pm 9$ & $128 \pm 5^{\circ}$ & $132 \pm 17^{c}$ & $117 \pm 13^{c}$ \\
12 & $99 \pm 7$ & $139 \pm 3^{\circ}$ & $150 \pm 10^{\circ}$ & $96 \pm 6$ \\
16 & $103 \pm 9$ & $162 \pm 6^{\circ}$ & $194 \pm 22^{\circ}$ & $111 \pm 12$ \\
24 & $116 \pm 17$ & $177 \pm 20^{\circ}$ & $200 \pm 31^{\circ}$ & $103 \pm 7$ \\
48 & $131 \pm 11^{\circ}$ & $250 \pm 19^{\circ}$ & $349 \pm 32^{c}$ & $137 \pm 11^{\circ}$ \\
72 & $145 \pm 10^{c}$ & $297 \pm 10^{\circ}$ & $405 \pm 31^{\circ}$ & $140 \pm 4^{c}$ \\
96 & $176 \pm 4^{\circ}$ & $369 \pm 30^{\circ}$ & $188 \pm 16^{\circ}$ & $157 \pm 17^{c}$ \\
120 & $170 \pm 16^{\circ}$ & $292 \pm 13^{\circ}$ & $377 \pm 37^{\circ}$ & $220 \pm 10^{c}$ \\
\hline
\end{tabular}

"Conditions were the same as described for" Fig. 1. The average control values were: protein, $21.7 \mathrm{mg} / \mathrm{g}$ liver; protoheme, $22.8 \mathrm{~m} \mu$ moles/g liver; ytochrome $\mathrm{P}-450,1.17 \mathrm{Ol})_{4: 0-490 \mathrm{~m} \mu} / \mathrm{g}$ liver; and eytochrome $b_{5}, 4.76$ m $\mu$ moles/g liver.

${ }^{b}$ Each value represents the mean \pm standard error of at lenst three experiments.

c $P<0.05$

TABLLE IV

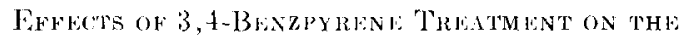
Conthat of Mremomate Prothin, Pliotohemf, and Crtochromes P-450 and b Per Gram of Tivera

\begin{tabular}{r|c|c|c|c}
\hline & \multicolumn{3}{|c}{ Percent of control } \\
\hline
\end{tabular}

Fig. 1. The average control values are given in Table III.

" Wach value represents the mean \pm standard error of at least three experiments.

$r<0.05$.

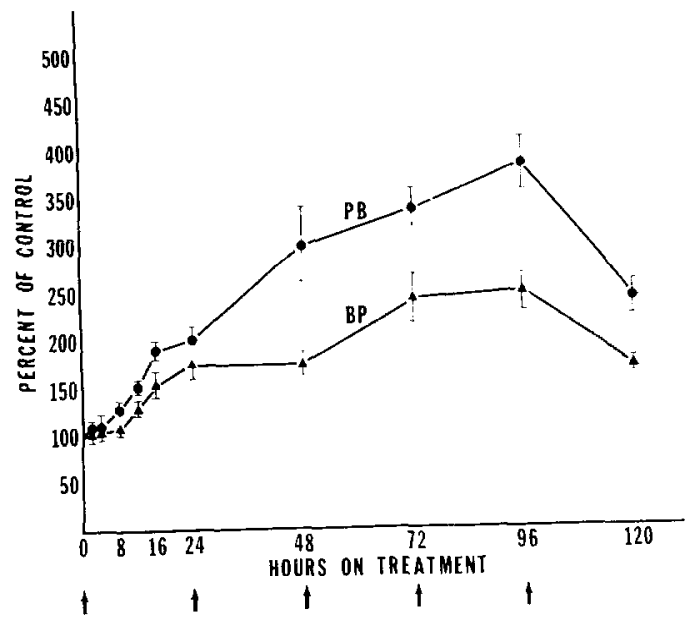

FIg. 3. Effects of phemobarbital and 3,4bencpyrene treatments on hepatic microsomal levels of cytochrome P-450. Couditions were the same as described for Fig. 1. Wach point represents the rnean of at least three experiments, and the brackets represent the standard crror of the mean. The average control value was $0.05 \mathrm{OI}_{450-490} \mathrm{~m} \mu$ / mg protein.

then progressively increased until, about 96 hr after the onset of treatment with either agent, a maximum was reached. However, between 96 and $120 \mathrm{hr}$, the levels of cyto chrome P-450 began to fall toward control values, although after 120 hr of treatment cytochrome P-450 levels were increased approximately 3 -fold by phenobarbital and about 2-fold by 3,4-benzpyrene. Increasing the doses of phenobarbital and 3,4-benzpyrene during the last $7.2 \mathrm{hr}$ of the study did not prevent cytochrome $\mathrm{P}$ ' 150 levels from declining after maximum stimulation was achieved. The observation that 3,4-benzpyrene-induced increase in cytochrome P-450 levels was about $50 \%$ of that produced by phenobarbital is consistent with the effectis of these agents on the activity of hepatic MaA synthetase, hepatic heme smthesis, and the lepatic microsomal content of protoheme. The rate of $\mathrm{P}-450$ increase in hepatic microsomes after phenobarbital atministration is similar to that observed by others $(3,30,31)$.

Unlike the stimulatory effects of phenobarbital and 3,4-benzpyrene on the hepatic microsomal content of eytochrome P-45), the levels of eytochrome $b_{5}$ in leppatic 


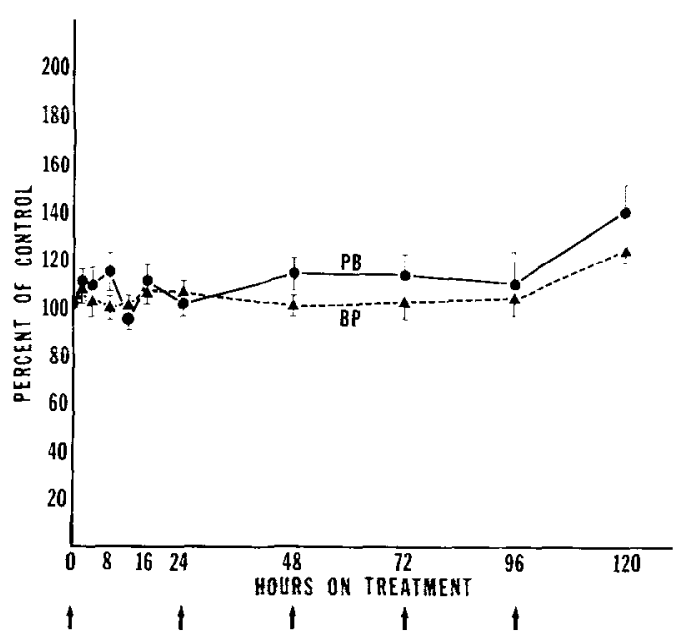

FIG. 4. Effects of phenobarbital and 3,4benzpyrene treatments on hepatic microsomal levels of cytochrome $b_{5}$. Conditions were the same as described for Fig. 1. Each point represents the mean of at least three experiments, and the brackets represent the standard error of the mean. The average control value was $0.22 \mathrm{~m} \mu$ moles of cytochrome $b_{5} / m g$ protein.

microsomes did not increase during the first $48 \mathrm{hr}$ of treatment, although, as seen in Fig. 4 , the amount of cytochrome $b_{5}$ per milligram of microsomal protein did increase $(P<0.05)$ between 96 and $120 \mathrm{hr}$ after the onset of treatment with either agent. However, when the data were expressed as the amount of microsomal cytochrome $b_{5}$ per gram of liver (Yables 11 I and IV), significant increases $(P<0.05)$ were observed at about $48 \mathrm{hr}$ after the onset of treatment with phenobarbital and after $72-96 \mathrm{hr}$ of 3,4 benzpyrene treatment. In agreement with the obscrvations of other investigators $(3,9$, 23 ), the degree of enhancement of cytochrome $b_{5}$ levels by these two agents was considerably less than their effects on cytochrome P-450 levels.

Effect of Phenobarbital and 3,4-Benzpyrene Treatments on Hepatic Microsomal Drug Oxidations and the Activity of Hepatic Microsomal NADPH-Cytochrome $c$ Reductase

The effects of phenobarbital on the hepatic microsomal demethylations of ethylmorphine, norcodeine, and $3-\mathrm{CH}_{3}-\mathrm{MAB}$ at 72 ,
96 , and $120 \mathrm{hr}$ after the onset of treatment are summarized in Table V. The stimulatory effects of phenobarbital on these enzymatic reactions during the initial $48 \mathrm{hr}$ of treatment have been previously reported (13). As seen in Table V, both the specific activities (rate per milligram of microsomal protein) and the total activities (rate per gram of liver) of these reactions remained at a fairly constant level above control values

\section{TABLE V}

Effects of Phenobarbital on Hepatic Microsomal Drug Oxidations and the Activity of Hipatic Microsomal NADPH-Cytochromit c Reductase at 72, 96, and $120 \mathrm{Hr}$ After the OnSET OF TREATMENT ${ }^{a}$

\begin{tabular}{|c|c|c|c|}
\hline \multirow[b]{2}{*}{ Measurement } & \multirow{2}{*}{$\begin{array}{l}\text { Hours } \\
\text { on } \\
\text { treat- } \\
\text { ment }\end{array}$} & \multicolumn{2}{|c|}{ Percent of control ${ }^{b}$} \\
\hline & & $\begin{array}{l}\text { Based on } \\
\text { specific } \\
\text { activity }\end{array}$ & $\begin{array}{l}\text { Based on } \\
\text { total activity }\end{array}$ \\
\hline \multirow{3}{*}{$\begin{array}{l}\text { Ethylmorphine } N \text { - } \\
\text { demethylation }\end{array}$} & 72 & $267 \pm 25$ & $436 \pm 37$ \\
\hline & 96 & $284 \pm 45$ & $430 \pm 38$ \\
\hline & 120 & $280 \pm 35$ & $413 \pm 30$ \\
\hline \multirow{3}{*}{$\begin{array}{l}\text { Norcodeine } O- \\
\text { demethylation }\end{array}$} & 72 & $147 \pm 18$ & $226 \pm 25$ \\
\hline & 96 & $149 \pm 23$ & $228 \pm 14$ \\
\hline & 120 & $162 \pm 18$ & $239 \pm 14$ \\
\hline \multirow{3}{*}{$\begin{array}{l}\text { 3- } \mathrm{CH}_{3}-\mathrm{MAB} N- \\
\text { demethylation }\end{array}$} & 72 & $276 \pm 29$ & $418 \pm 21$ \\
\hline & 96 & $258 \pm 52$ & $364 \pm 27$ \\
\hline & 120 & $273 \pm 58$ & $398 \pm 68$ \\
\hline \multirow{3}{*}{$\begin{array}{l}\text { NADPH-cytochrome } \\
\text { c reductase }\end{array}$} & 72 & $200 \pm 21$ & $330 \pm 31$ \\
\hline & 96 & $211 \pm 39$ & $320 \pm 31$ \\
\hline & 120 & $227 \pm 21$ & $339 \pm 40$ \\
\hline
\end{tabular}

${ }^{a}$ Rats received intraperitoneal injections of phenobarbital $(40 \mathrm{mg} / \mathrm{kg})$ every 24 hours, while control rats received an equal volume of $0.9 \%$ $\mathrm{NaCl}$.

${ }^{b}$ Each value represents the mean \pm standard error of at least three experiments. $P<0.05$ for all values.

- The average control values for demethylations (m $\mu$ moles $\mathrm{HCHO} / \mathrm{mg}$ protein $/ \mathrm{min}$ ) were 3.42 for ethylmorphine, 0.95 for norcodeine, and 0.67 for $3-\mathrm{CH}_{3}-\mathrm{MAB}$, while the average control value for NADPH-cytochrome c reduetase was $49.1 \mathrm{~m} u$ moles of cytochrome $\mathrm{c}$ reduced/mg protein $/ \mathrm{min}$.

${ }^{d}$ The average control values for demethylations ( $\mu$ moles $\mathrm{HCHO} / \mathrm{g}$ liver $/ \mathrm{hr}$ ) were 6.00 for ethylmorphine, 1.71 for norcodeine, and 1.17 for 3- $\mathrm{CH}_{3}-\mathrm{MAB}$, while that for NADPH-cytochrome c reductase was $93.1 \mu$ moles of cytochrome e reduced/g liver/hr. 
during these late time periods and did not decrease toward control levels as did the hepatic microsomal content of cytochrome P-450 (Fig. 3 and Table III). These observations suggest that, at least after stimulation has oceurred, the content of cytochrome P-450 in hepatic microsomes is of sufficient magnitude so as not to limit the hepatic microsomal oxidation of either ethylmorphine, norcodeine, or $3-\mathrm{CH}_{3-\mathrm{IAB}} \mathrm{IA}$

The effects of 3,4-benzpyrene on the activity of hepatic microsomal $\mathrm{TADPH}-$ cytochrome c reductase and the $N$-demethrlation of $3-\mathrm{CH}_{3}-\mathrm{MAB}$ by hepatic microsomes at $7 \%, 96$, and 120 hr after the onset of treatment are summarized in Table VI. The effects of 3,4-benzpyrene on these reactions during the initial $48 \mathrm{hr}$ of treatment have been described previously (10). AIthough 3,4-benzpyrene did not stimulate the $N$-demethylation of ethylmorphine or the $O$-demethylation of norcodeine by hepatic microsomes (Table VII), the hepatic microsomil $\mathrm{N}$-demethylation of $3 \mathrm{CH}_{3}$ $\triangle A B$ was observed to increase progressively unt il maximum stimulation was achieved at approximately $72 \mathrm{hr}$ after the onset of treatment. Once maximum stimulation was produced, $N$-demethylase activity remained constant at a level significantly greater than control values. Unlike its effects on the $N$-demethylation of $3-\mathrm{CH}_{3}-\mathrm{MAB}, 3,4$-benzpyrene treatment did not result in an increase in the specific activity of $\mathrm{XADPH}$ cytochrome c reductase at any time through-

\section{TABLE: VI}

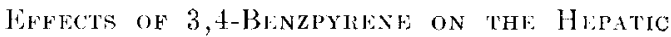
Microsomal N-I) MAB iNI) THF: ACTIVITY of NADPH-CrToCHROML a REDCCRAS AT 72, 96, ANI $1201 \mathrm{HR}$ AFTli: "HH: ONSF, OF TrEATMEN"

\begin{tabular}{|c|c|c|c|}
\hline \multirow[b]{2}{*}{ Measurement } & \multirow{2}{*}{ 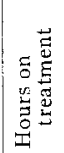 } & \multicolumn{2}{|c|}{ Percent of control ${ }^{b}$} \\
\hline & & $\begin{array}{l}\text { Based on } \\
\text { specific } \\
\text { activity }\end{array}$ & $\begin{array}{l}\text { Based on } \\
\text { total activity }\end{array}$ \\
\hline $\begin{array}{l}\text { 3-CH }-\mathrm{MAB} \mathrm{Y}- \\
\text { demethylation }\end{array}$ & $\begin{array}{r}72 \\
96 \\
120\end{array}$ & $\mid \begin{array}{l}243 \pm 19 c \\
212 \pm 31^{\circ} \\
212+41^{\circ}\end{array}$ & $\begin{array}{l}292 \pm 50 c \\
27+ \pm 20 \\
275+22 c\end{array}$ \\
\hline $\begin{array}{l}\text { NAIPH cytochrome } \\
\text { c reductase }\end{array}$ & $\begin{array}{r}72 \\
96 \\
120\end{array}$ & $\begin{aligned} 112 & \pm 8 \\
102 & \pm 7 \\
97 & \pm 10\end{aligned}$ & $\begin{array}{l}128+18^{\circ} \\
135 \pm 17^{\circ} \\
107+12\end{array}$ \\
\hline
\end{tabular}

"laats received intraperitoneal injections of 3,4-benzpyrene (20 $\mathrm{mg} / \mathrm{kg}$ ) every $24 \mathrm{hr}$, while control rats received an equal volume of com oil. The average control values ate given in Table $Y$.

${ }^{b}$ Each value represents the mean \pm standard error of at least three experiments.

$P<0.05$.

\section{TABLE VII}

Lefecjs of Treatments wite Phexobaritide, 3, 4-Benzpyrene, and the Combrnaton of Phexo-

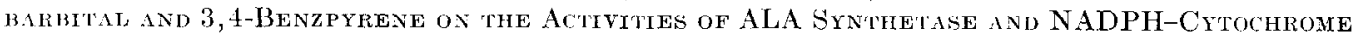
c Reductase, Hepatic Microsomal Levels of Cytochrome P-450, ind IIepatic Microsomal DRUG OXIDATIONS

\begin{tabular}{lcccc}
\multicolumn{1}{c}{ Measurement } & $\begin{array}{c}\text { Hours on } \\
\text { treatment }\end{array}$ & Phenobarbital & Activity or amount ${ }^{b}$ & Phenobarbital and \\
3,4-benzpyrene
\end{tabular}

${ }^{a}$ Lats received intraperitoneal injections of phenobarbital $(40 \mathrm{mg} / \mathrm{kg}$ and/or 3,4 -benzpyrene 20 $\mathrm{mg} / \mathrm{kg})$ every $24 \mathrm{hr}$ and were sacrificed at the times indicated. The average control values were ALA synthetase, $16.0 \mathrm{~m} \mu$ moles of ALA formed/g liver/hr; cytochrome P-450, $1.31 \Delta O D / g$ liver; NADPIIcytochrome e reductase, $95.0 \mathrm{mumoles}$ of cytochrome $\mathrm{c}$ reduced $/ \mathrm{g}$ liver $/ \mathrm{hr}$; ethylmorphine $N$-demethylation $6.05 \mathrm{~m} \mu$ moles $\mathrm{HCHO} / \mathrm{g}$ liver $/ \mathrm{hr}$; norcodeine $O$-demethylation, $19.6 \mu \mathrm{moles} \mathrm{HCHO} / \mathrm{g}$ liver/hr; and $3-\mathrm{CH}_{3}-\mathrm{MAB} N$-demethylation, $1.17 \mu$ moles $\mathrm{HCHO} / \mathrm{g}$ liver/hr.

${ }^{b}$ Each value represents the mean \pm standard error of at least three experiments. 
out this study, although the activity of this enzyme per gram of liver was increased slightly at 72 and $96 \mathrm{hr}$. These observations are comsistent with the view (10) that $\mathrm{NADPH}$-ytochrome $\mathrm{c}$ reductase may not be the rate-limiting component in those hepalic microsomal oxidations which are stimulated by 3,4-benzpyrene.

\section{Effects of the Simultaneous Administration of} Phenobarbital and 3,4-Benzpyrene

Although phenobarbital and 3,4-benzpyrene treatments both resulted in the enhancement of hepatic ALA synthetase activity, hepatic heme synthesis, and hepatic microsomal levels of cytochrome P-450, the observation that phenobarbital stimulated the hepatic microsomal demethylations of ethylmorphine, norcodeine, and $3-\mathrm{CH}_{3}-$ $\mathrm{MAB}$ and the activity of $\mathrm{NADPH}$-cytochrome c reductase, while 3,4-benzpyrene had minimal effect on NADPH-cytochrome c reductase activity and stimulated the hepatic microsomal demethylation of $3-\mathrm{CH}_{3^{-}}$ MAB only, suggests that more than one mechanism of induction may exist. Evidence supporting the view that different mechanisms are involved in producing the stimulatory effects observed when phenobarbital and 3,4-benzpyrene are administered has come from studies in which maximum stimulatory doses of these agents are administered simultaneously to animals. These studies are based on the premise that if a single inductive mechanism is involved, then when either agent is administered at a dose known to produce maximum stimulation, the addition of the other agent should not produce an additional response. If, on the other hand, different mechanisms are involved, the sum of the maximum effects resulting when each agent is employed alone would be observed when they are administered together.

During the initial studies of this investigation, the administration of phenobarbital at a dose of $40 \mathrm{mg} / \mathrm{kg}$ and 3,4-benzpyrene at a dose of $20 \mathrm{mg} / \mathrm{kg}$ was found to produce maximum stimulation of the parameters studied. As seen in Table VII, the stimulatory effects of phenobarbital and 3,4benzpvrene on the activity of hepatic ALA sinthetase were not additive at either 12 or
$72 \mathrm{hr}$ after the onset of treatment. This observation suggests that phenobarbital and 3,4-benzpyrene stimulate hepatic ALA synthetase activity and thus result in the enhancement of hepatic heme synthesis by the same or similar mechanisms. However, in agreement with the findings of Sladek and Mannering $(4,24)$, an additive response was observed in the enhancement of both cytochrome P-450 levels in hepatic microsomes and the $N$-demethylation of $3-\mathrm{CH}_{3-\mathrm{MAB}} \mathrm{MAB}$. No additive effects were obscrved on the hepatic microsomal demethylations of ethylmorphine or norcodeine or on the activity of hepatic microsomal NADPH-cytochrome c reductase, reactions which are not affected by 3,4-benzpyrene treatment.

\section{ISCUSSION}

Treatment of rats with either phenobarbital or 3,4-benzpyrene was found to result in the rapid and marked stimulation of the activity of hepatic ALA synthetase, the proposed initial and rate-limiting enzyme in hepalic heme biosynthesis $(11,12)$. Increases in the activity of this enzyme were observed as early as $2 \mathrm{hr}$ after phenobarbital administration and $4 \mathrm{hr}$ after the administration of 3,4-benzpyrene. This stimulation appears to result from the increased de novo synthesis of ALA synthetase. Although the magnitude of stimulation resulting from treatment with 3,4-benzpyrene was approximately $50 \%$ of that observed after phenobarbital treatment, no additive stimulation of hepatic ALA synthetase activity was observed when animals were treated simultaneously with both agents. This observation suggests that phenobarbital and 3,4-benzpyrene stimulate the synthesis of ALA synthetase by similar or closely related mechanisms.

Stimulation of hepatic ALA synthetase activity was closely followed by an increased incorporation of labeled heme precursor into hepatic mierosomal heme in vivo. The enhancement of the liver's capacity to synthesize heme in vivo appeared to precede increases in the hepatic microsomal content of protoheme and cytochrome P-450. Furthermore, the observation that changes in the hepatic microsomal levels of cytochrome P-450 followed the changes in the 
activity of hepatic ALA synthetase and in the capacity of the liver to synthesize microsomal heme in vivo suggests that heme synthesis may be the controlling event in the synthesis of hepatic microsomal cytochrome P-450. In this respect, decreases in the degree of stimulation of hepatic AIA synthetase activity, the liver's capacity to synthesize microsomal heme in vivo, and cytochrome P-450 and protoheme levels in hepatic microsomes observed during the late time periods in these studies might be explained on the basis of feedback repression of ALA synthetase by heme as suggested by Granick (12, 19, 25).

Although the hepatic microsomal levels of cytochrome P-450 and protoheme became elevated during the initial 12 hr of I reatment. with either phenobarbital or 3,4-benzpyrene, the content of cytochrome $b_{5}$ in hepatic microsomes remained unchanged during the first $4 \mathrm{~s} \mathrm{hr}$ of treatment. These observations may be explained on the basis of the relatively slow turnover rate which eytochrome $b_{5}$ has been observed to exhibit $(26,27)$, since a slow rate of turnover would result in a delayed appearance of a response to any changes in the rate of synthesis of the hemoprotein.

The observations that phenobarbital treatment resulted in the stimulation of the hepatic microsomal oxidations of ethylmorphine, norcodeine, and $3-\mathrm{CH}_{3}-\mathrm{MAB}$, as well as $\mathrm{NADP} H$-cytochrome $\mathrm{c}$ reductase activity, while 3,4-benzpyrene treatment resulted in the stimulation of the $N$-demeth-

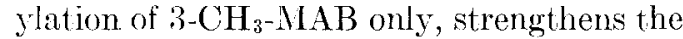
view that differences exist in the mechanism or mechanisms by which phenobarbital and 3,4-benzpyrene stimulate the hepatic microsomal drug-metabolizing system. In accordance with this, and in agreement with the observations of Sladek and Manmering (4, 24), the stimulatory effects of phenobarbital and 3,4-benzpyrene on hepatic microsomal cytochrome P-450 and on the $N$-demethylation of $3-\mathrm{CH}_{3}-\mathrm{MAB}$ were additive.

Since phenobarbital and 3,4-benzpyrene appear to stimulate the activity of hepatic ALA synthetase, and enlance hepatic heme synthesis by the same or closely related mechanisms, the results of these studies may be interpreted as indicating that the differ- ences observed between the stimulatory actions of phenobarbital and 3,4-benzpyrene are due primarily to differences in the effects of these agents on the syntheses of certain hepatic microsomal proteins. This is consistent with the proposal that the species of cytochrome P-450 induced by 3,4-benzpyrene and related compounds may be different from that induced by phenobarbital $(4,24,28,29)$. In accordance with this proposal, "cytochrome P-450" may actually consist of a group of closely related cytochromes, each of which functions as a terminal oxidase in the metabolism of a limited number of substrates. Since certain protein moieties may confer different specificities to cytochrome P-450, the possibility exists that the differences observed between the stimulatory effects of phenobarbital and 3,4-benzpyrene may be due to the differential stimulation of the syntheses of these different apocytochromes. Another possibility which exists is that several specific substrate-binding proteins may function in the transport and positioning of substrates on cy tochrome P-450, and phenobarbital and 3,4-benzpyrene may selectively activate and/or stimulate the synthesis of some of these proteins without influencing others. A greater specificity in the enhancement of hepatic microsomal protein synthesis by 3,4-benzpyrene may account for its lack of effect on the hepatic microsomal oxidations of ethylmorphine on norcodeine, as well as on the activity of hepatic microsomal $\mathrm{XADPH}$ cytochrome c reductase.

Although differences in the mechanisms of stimulation appear to exist, the following sequence of events can be postulated 10 occur during the complex process which ultimately results in the stimulation of certain hepatic microsomal drug oxidations. The administration of an inducing agent such as phenobarbital or 3,4-benzpyrene? produces a rapid and marked increase in the activity of hepatic ALA synthetase which, in turn, results in the enhancement of hepatic heme synthesis. Stimulation of hepatic heme synthesis leads to the increased synthesis of hepatic microsomal oxidations of certain drugs and carcinogens.

In these studies, ALA synthetase activity increases to an extent which is greater than 
the increase in glycine incorporation into microsomal heme. Assuming that ALA synthetase is rate limiting in heme synthesis $(11,12)$, this suggests that the activity as measured in vitro in the homogenate does not reflect functional ALA synthetase activity in vivo. Several explanations are possible. About $40 \%$ of ALA synthetase activity after administration of allylisopropylacetamide $(32,33)$ is found in the cytosolic fraction of the hepatic cell. If increases of ALA synthetase after phenobarbital and 3,4-benzpyrene are also, in part, cytosolic it may be that this fraction of the enzymatic activity is not functional due to inaccessability of succinyl$\mathrm{CoA}$. Indeed, we have found recently that cytosolic ALA synthetase activity does increase after phenobarbital treatment (unpublished observations). Another possibility is that ALA synthetase activity in vivo is under a certain degree of inhibition from which it is released after homogenization. Recently, Scholnick et al. (33) have shown that soluble ALA synthetase activity is inhibited by heme in vitro. However, in the present studies the pattern of increases and decreases of ALA synthetase activity after chronic administration of phenobarbital and 3,4-benzpyrene is strikingly similar to that observed when heme synthesis was studied.

\section{REFERENCES}

1. Conney, A. H., Pharmacol. Rev. 19, 317 (1967).

2. Mannering, G. J., in "Importance of F'undamental Principles of 1)rug Evaluation" (I). H. Tedeschi and R. L. Tedeschi, eds.), p. 105. Raven Press, New York (1968).

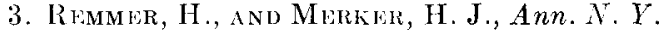
Acad. Sci. 123, 79 (1965).

4. Sladek, N. F., ind Mannlerina, G. J., Mol. Pharmacol. 5, 174 (1969).

5. Cooprr, D. Y., Levix, S., NarasimhtuU, S., Rosenthat, O., ann Fstabrook, R. W., Science 147, 400 (1965).

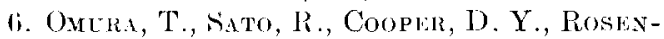
Thal, O., As listabook, R. W., Fed. Proc. Fed. Amer. Sor. Exp. Biol. 24, 1181 (1965).

7. Marvier, H. S., Schmid, R., and Sohutzit, H., Biochem. Biophys. Res. Commun. 33, 969 (1968).

8. Whi, O., Yano, Y., Uniт, G., ауд Nakio, K., Biochem. Pharmacol. 17, 595 (1968).

9. Marver, HI. S., in "Microsomes and I)rug Oxidations" (J. R. Gillette, A. H. Comney,
G. J. Cosmides, R. W. Estabrook, J. R. Fouts, and (G. J. Mannering, eds.), p. 495, Academic Press, New York (1969).

10. Biron, J., And ThPhly, T. R., Biochem. Biophys. Res. Commun. 36, 526 (1969).

11. Granick, S., and Urati, G., J. Biol. Chem. 238, 821 (1963).

12. Granick, S., J. Biol. Chem. 241, 1359 (1966).

13. Banon, J., And Tephly, T. R., Mol. Pharmacol. 5, 10 (1969).

14. Nishibayashi, H., and Sato, R., J. Biochem. Tokyo 61, 491 (1967).

15. Marver, H. S., Tschudy, D. P. Perlioth, M. G., And Coluins, A., J. Biol. Chem. 241, 2803 (1966).

16. Tschudy, D. P., Wraland, F. H., Collixs, A., And Huntwn, G., Jn., Metabolism 13, 396 (1964).

17. Irving, E. A., and Eldiote, W. H., J. Biol. Chem. 244, 60 (1969).

18. Granick, S., J. Biol. Chem. 238, PC 2247 (1963).

19. Granick, S., Ann. N. Y. Acad. Sci. 123, 188 (1965).

20. Conney, A. H., Davison, C., Gastel, R., Ani Burns, J. J., J. Pharmacol. Exp. Ther. 130, 1 (1960).

21. Connty, A. H., and Gilman, A. G., J. Biol. Chem. 238, 3682 (1963).

22. Remmer, H., and Merker, H. J., Science 142, 1657 (1963).

22. Schmid, R., Marver, H. S., and Hammaklir, L., Biochem. Biophys. Res. Commun. 24, 319 (1966).

24. Stadik, N. E., and Mannering, G. J., Mol. Pharmacol. 5, 186 (1969).

25. Kappas, A., and (tranick, S., J. Biol. Chem. 243, 346 (1968).

26. Kuriyama, Y,, Omura, T., Siekfvitz, P., and Palade, G. F., .J. Biol. Chem. 244, 2017 (1969).

27. Schimke, R. T., Ganschow, R., Doyle, D., and Aris, T. M., Fed. Proc. Fed. Amer. Soc. Exp. Biol. 27, 1223 (1968).

28. Sladek, N. E., and Mannering, G. J., Biochem. Biophys. Res. Commun. 24, 668 (1966).

29. Hildebrandt, A., Rfmmer, H., and Estaввоок, R. W., Biochem. Biophys. Res. Commun. 30, 607 (1968).

30. Grfim, H., Sohlinman, J. B., Klotziüehler, M., AND Rlimmer, H., Biochim. Biophys. A cla 201, 20 (1970).

31. Orrenits, S., J. Cell Biol. 26, 725 (1965).

32. Hayashi, N., Yonı, B., and KikUchi, (.., Arch. Biochem. Biophys. 131, 8:3 (1969).

33. Scholntek, P. I., Hammiker, L., AND Marven, II., Proc. Nat. Acad. Sci. U. S.63, $65(1969)$. 